\title{
Infectious diseases mortality in central Serbia
}

\author{
Hristina D Vlajinac, Jelena M Marinković Nikola I Kocev, Benko J Adanja, \\ Tatjana D Pekmezović, Sandra B Šipetić, Dejan D J Jovanović
}

\begin{abstract}
Study objective - To determine the influence and the effect of the war in the former Yugoslavia and of the United Nations economic sanctions on mortality from infectious diseases.

Design - This was a descriptive study analysing mortality data time series. Setting - Central Serbia, Yugoslavia.

Participants - The population of central Serbia was the subject of the study (about six million inhabitants).

Measurements - Mortality rates were standardised directly, using the "European population" as the standard. Regression analysis and analysis of covariance were undertaken.

Main results - During the period 1973-93, mortality from infectious diseases showed a decreasing trend. From 1987-90, and in both men and women, mortality from infectious diseases was significantly higher than expected on the basis of the trend for the preceding period $(p=0.020$ and $p=$ $0.000)$. In addition, there was a statistically significant departure from the preceding trend $(p=0.036)$ in men between 1991 and 1993 (the period of the war and UN sanctions) - the main effect being in younger age groups.

Conclusion - The economic crisis in the former Yugoslavia during the 1980 s followed by the outbreak of the war and the damaging effects of UN economic sanctions had a distinctly adverse effect on mortality from infectious diseases.
\end{abstract}

( $(\mathcal{F}$ Epidemiol Community Health 1997;51:172-174)

Institute of

Epidemiology, School of Medicine, Belgrade University,

Višegradska 26

PO Box 456, 11000

Belgrade, Yugoslavia

H D Vlajinac

B K Adanja

T D Pekmezović

S B Špetić

D J Jovanović

Institute for Social Medicine, Statistics and Health Research,

School of Medicine,

Belgrade University,

Yugoslavia

J M Marinković

N I Kocev

Correspondence to: Dr H Vlajinac.

Accepted for publication July 1996
In 1991 the civil strife which led to the war and the break up of the former Yugoslavia began. The United Nations (UN) imposed economic sanctions on Serbia and Montenegro, which made up the new rump Yugoslavia in May 1992. Serbia was under sanctions for more than three and half years until these were suspended in November 1995.

This work is a part of the investigation undertaken in order to assess the effect of the war and the UN sanctions on the health of the population.

\section{Methods}

The investigation was performed in central Serbia - that is, the Republic of Serbia excluding the provinces of Kosovo and of Vojvodina. The period 1973-93 was observed.
Mortality data were derived from published and unpublished material of the Federal Institute of Statistics. ${ }^{1}$

Age adjustment of the yearly mortality rates was carried out by a direct method using the distribution of the "European population" ${ }^{2}$ as the standard.

The least square method was used to fit mortality rates to different trend curves (linear, logarithmic, inverse, and quadratic). Linear trend was used whenever it significantly $(p<0.05)$ represented existing mortality rates. To measure the possible effect of the war and the sanctions (WAS) on infectious diseases mortality between 1991 and 1993, it was necessary to modify the simple linear regression model. A dummy variable (variable WAS) consisting of 0 's and 1 's, was created to signify the passage from the period before and the period after the beginning of the war and the sanctions. ${ }^{3}$

Analysis of covariance was used to compare linear regression slopes.

\section{Results}

During the period 1973-93, mortality from infectious diseases (ICD codes 001-139) showed a decreasing trend (Figure 1). The same tendency was present in all age groups except 15-24 years and 25-34 years for males and $0-4$ for females (table 1 ).

When the possible effects of the war and of the sanctions were investigated, it appeared that in men the effect of the WAS variable on the linear regression model of standardised mortality rates was statistically significant $(p=$ $0.036)$. The linear regression equation for men was:

$$
\begin{gathered}
\mathrm{y}=17.74-0.79 \mathrm{X} \text { (time) }+ \\
\text { 7.77 WAS (1991-1993 year) }
\end{gathered}
$$

In other words, during the period 1991-93, infectious disease mortality differed from the values expected on the basis of preceding trend - that is, the mortality trend decreased more slowly than expected. In women the difference between the observed and expected trends was not significant.

Linear regression slopes of mortality rates in age groups from 35 to 84 years did not differ significantly in either men or in women $(f=$ $2.175 \mathrm{df}=4 ; 95 \mathrm{p}=0.078$ and $\mathrm{f}=2.052 \mathrm{df}=4$; $95 \mathrm{p}=0.093$ respectively). When linear regression slopes of mortality rates of the same age groups were compared with linear regression slopes of standardised mortality rates, significant differences were found for men $(f=$ $2.93 \mathrm{df}=5 ; 114 \mathrm{p}=0.012$ ), but not for women 


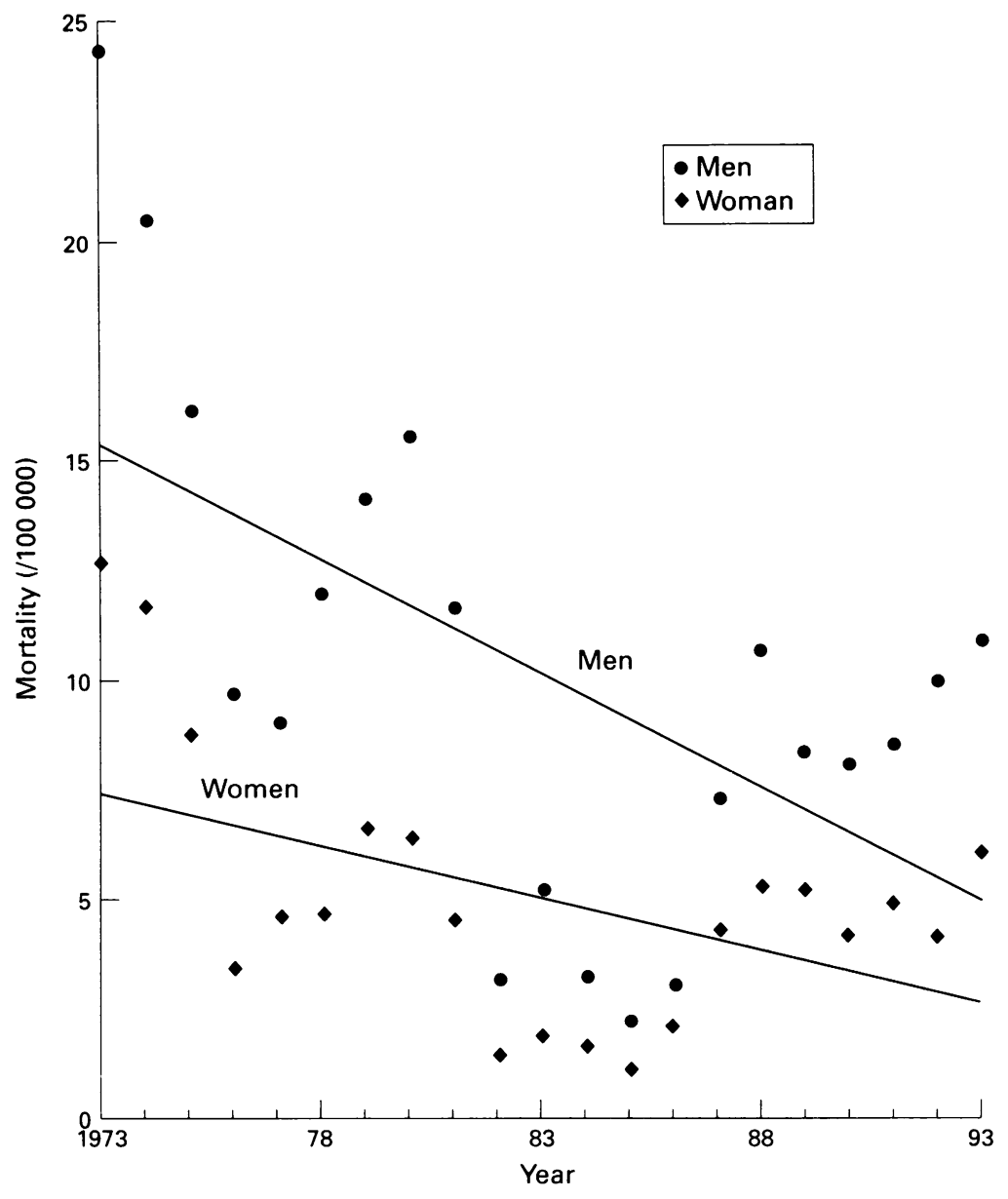

Figure 1 Standardised mortality rates (per 100000) and mortality trends for infectious diseases in central Serbia in relation to gender, 1973-93.

Table 1 Regression equation of infectious disease mortality in relation to gender and age in central Serbia, 1973-93

\begin{tabular}{lll}
\hline & \multicolumn{2}{l}{ Regression equation } \\
\cline { 2 - 3 } Age group & Men & Women \\
\hline $0-4$ & $\mathrm{y}=8.471+47.556 / \mathrm{X}$ & $\mathrm{y}=41.176-5.765 \mathrm{X}+0.244 \mathrm{X}^{2}$ \\
$5-14$ & $\mathrm{y}=0.152+1.430 / \mathrm{X}$ & $\mathrm{y}=0.039+2.259 / \mathrm{X}$ \\
$15-24$ & $\mathrm{y}=1.398-0.215 \mathrm{X}+0.010 \mathrm{X}^{2}$ & $\mathrm{y}=0.286+1.169 / \mathrm{X}$ \\
$25-34$ & $\mathrm{y}=3.577-0.569 \mathrm{X}+0.026 \mathrm{X}^{2}$ & $\mathrm{y}=0.574+2.818 / \mathrm{X}$ \\
$35-44$ & $\mathrm{y}=7.085-0.240 \mathrm{X}$ & $\mathrm{y}=3.860-0.176 \mathrm{X}$ \\
$45-54$ & $\mathrm{y}=18.353-0.708 \mathrm{X}$ & $\mathrm{y}=5.820-0.241 \mathrm{X}$ \\
$55-64$ & $\mathrm{y}=30.428-1.022 \mathrm{X}$ & $\mathrm{y}=11.667-0.427 \mathrm{X}$ \\
$65-74$ & $\mathrm{y}=54.913-1.830 \mathrm{X}$ & $\mathrm{y}=21.548-0.707 \mathrm{X}$ \\
$75-84$ & $\mathrm{y}=74.304-2.299 \mathrm{X}$ & $\mathrm{y}=39.075-1.159 \mathrm{X}$ \\
$85+$ & $*$ & $\mathrm{y}=7.651-0.236 \mathrm{X}$ \\
Total & $\mathrm{y}=15.849-0.514 \mathrm{X}$ &
\end{tabular}

*None of the theoretical regression models apply.

$(f=2.154 \mathrm{df}=5 ; 114 \mathrm{p}=0.056)$. According to these results, it can be concluded that the change in the standardised mortality trend in men was caused by changes in the mortality of younger age groups.

Taking into account the fact that economic recession prevailed in the country even before 1991, and in order to separate the effect of the war and the sanctions from other factors, the mortality trend was observed from 1973-90. Again a dummy variable was created. Going backwards from the year 1990 and including a dummy variable year by year, it appeared that some factors present during the period 1987-90 slowed down the decreasing trend of infectious disease mortality. The observed/expected difference was significant in both men $(\mathrm{p}=$ $0.020)$ and women $(p=0.000)$. The linear regression equation for men was:

$$
\begin{gathered}
\mathrm{y}=20.87-1.36 \mathrm{X} \text { (time) }+ \\
8.498 \text { dummy }(1987-1990 \text { year })
\end{gathered}
$$

The linear regression equation for women was:

$$
\begin{gathered}
\mathrm{y}=10.11-0.66 \mathrm{X}(\text { time })+ \\
6.702 \text { dummy }(1987-1990)
\end{gathered}
$$

\section{Discussion}

Our results show that during 1987-90, male and female mortality from infectious diseases was significantly higher than expected on the basis of the trend for the preceding period. In addition, a statistically significant departure from the preceding trend was observed in men during the period 1991-93.

The observed changes in infectious disease mortality could be explained by the deteriorating performance of the Yugoslav economy and the resulting fall in the living standard of average Yugoslav citizens. The Yugoslav economy experienced steady growth in the 1970 s, but throughout the 80 s growth was non-existent and recession prevailed. Unfavourable structural changes which took place in the economy were not always reflected in the total production levels, but are best reflected in the data on the real personal income level, which in the period 1981-90 was reduced by $31 \%{ }^{4}$ In spite of the deteriorating economic performance and the falling standard of living, the quality of the health service was not immediately affected, in line with the prevailing socialist philosophy that in high priority areas such as health services existing standard must be maintained at all cost. Such a policy did produce results for some time, which is supported by the fact that the lowest mortality rates from infectious diseases were recorded in the period 1982-85. Bearing in mind that diagnosis of death causes was improved during the period and that the proportion of deaths associated with ill defined symptoms and conditions (codes 780-796, ICD-8 and codes 780799 , ICD-9) during that period was greatly reduced (an average of $5 \%$ for the period 1982-85 compared with an average of $16 \%$ for the period 1973-81), ${ }^{1}$ low mortality rates could not be caused by systematic bias in the reporting of the infectious diseases mortality during those years. Rather it could be attributed to the successful performance of the health service in its actions aimed at preventing morbidity and mortality from these diseases.

However, as the recession deepened during the 80 s it was widely recognised that the country was not dealing with a temporary crisis in the economy, but rather with the crisis of the system itself. With that in mind, it is not at all surprising that mortality rates from infectious diseases showed a deteriorating trend in the period 1987-90.

The war in the former Yugoslavia that broke up in 1991 dealt a heavy blow to an already shaken and battered economy. Beginning with the year 1991, the bloated and unstable eco- 
nomy, propped up by Western loans, collapsed owing to the cost of war, loss of trade and economic cooperation between the warring republics, the effect of the economic sanctions imposed by UN, and the influx of more than half a million refugees. During the period 1991-93 industrial production fell to about $50 \%$ of the 1990 level, economic and social conditions sharply deteriorated, the country was ravaged by hyperinflation, and the living standard of the population was reduced to one third of the 1990 level. Restrictions imposed on trade through the economic embargo caused extreme hardship to medical services as well. These were disrupted due to lack of medical equipment and proper maintenance of the existing equipment, lack of vaccines, drugs and other medical inputs, as well as by lack of funding. As reported by Black, ${ }^{5}$ before the war over $80 \%$ of pharmaceutical products and over $95 \%$ of all medical equipment were imported and raw materials for what was left of the pharmaceutical industry were not exempt from sanctions. Medicines were still nominally free, but for the most part were not available. They had to be bought in the black market at black market prices. The health service had to take care of a large number of wounded coming from Bosnia as well as refugees. ${ }^{6}$ Medical services were administered on a priority basis and for urgent cases only, because the health service could not cope with all its tasks. Although formally exempt from embargo, medical supplies were badly affected by bureaucratic hurdles while waiting for approval by the UN sanctions committee, which added months of delay and made foreign suppliers unwilling to trade in some cases. ${ }^{7}$

Although not designed to do so, sanctions were contributing to the collapse of the health service and were blocking humanitarian aid efforts. ${ }^{5}$ The situation in Serbia during 1991-93 was very similar to experiences in Nicaragua and Cuba. A low-intensity war in Nicaragua from 1983-87 had a far reaching impact on the health and health services in that country. The war resulted in decreasing accessibility and availability of services, leaving about $10 \%$ of the population without access to modern health facilities. Population movements, resettlement to areas where preventive care had been unavailable, and war related destruction of the primary care infrastructure were associated with epidemics of malaria, diarrhoeal diseases, measles, leishmaniasis, meningitis, and tuberculosis. ${ }^{89}$

When in 1992 the 33 year old US embargo against Cuba was tightened with the passage of The Cuban Democracy Act to include trade mostly in food and medicines, the general standard of living and the quality of health services declined dramatically. While overall the health of the Cuban population was not yet seriously eroded, some infectious diseases, such as venereal diseases, diarrhea, and hepatitis A were on the rise, as were anaemia and nutritionally related health problems. ${ }^{10}$

Although there were no military operations on the territory of Serbia, and consequently no structural damage from war operations, the compounded impact of the economic crisis, the war in former Yugoslavia, and UN imposed economic sanctions against the rump Yugoslavia inevitably produced effects similar to those already seen in Nicaragua, Cuba, and other war-torn countries, ${ }^{11} 12$ brought the health system very close to collapse, and helped to create conditions that favoured the development of infectious diseases. It can therefore be reasonably concluded that the economic crisis and the absence of sustainable growth in the economy followed later by the outbreak of the war and the damaging effects of UN economic sanctions had a distinctly adverse effect on the mortality from infectious diseases.

Funded by the Ministry for Science and Technology of Serbia through contract No 8774, 1991-5.

1 Federal Institute of Statistics. Demographic statistics. Belgrade: Federal Institute of Statistics, 1975-1992.

2 Waterhouse J, Muir C, Correa P, Powell J, eds. Cancer incidence in five continents. Volume III. Lyon: IARC, 1976.Scientific Publication no 15

3 Tripp P. A comparative analysis of health care costs in three selected countries: the United States, the United Kingdom and Australia. Soc Sci Med 1981;15C:19-30.

4 Federal Institute of Statistics. Statistical yearbook of Yugoslavia. Belgrade: Federal Institute of Statistics, 1991.

5 Black ME. Collapsing health care in Serbia and Montenegro. $B M \mathcal{F}$ 1993;307:1135-7.

6 Acheson $D$. Health, humanitarian relief and survival in former Yugoslavia. BMf 1993;307:44-8.

7 Tosic O. Serbia: Disintegration of health-care system. Lancet 1992;340:295-6.

8 Garfield RM, Frieden T, Vermund SH. Health-related outcomes of war in Nicaragua. Am $\mathcal{f}$ Public Health 1987;77: comes of

9 Garfield RM. War - related changes in health and health services in Nicaragua. Soc Sci Med 1989;28:669-76.

10 Kuntz D. The politics of suffering: The impact of the US embargo on the health of the Cuban people - report of a fact-finding trip to Cuba, June 6-11, 1993. Int $\mathcal{F}$ Health Services 1994;24:161-79.

11 Ascherio A, Chase R, Coté T, Dehaes G, et al. Effect of the Gulf war on infant and child mortality in Iraq. $N$ Engl $\mathscr{f}$ Med 1992;327:931-6.

12 Kanji N, Harpham T. From chronic emergency to development: analysis of the health of the urban poor in 